\title{
Changes in the silver fir forest vegetation 50 years after cessation of active management
}

\author{
Beata Woziwoda*, Dominik Kopeć \\ Department of Geobotany and Plant Ecology, University of Łódź, Banacha 12/16, 90-237 Łódź, Poland
}

\begin{abstract}
Knowledge of the vegetation and the monitoring of its changes in preserved areas is an essential part of effective conservation policy and management. The aim of this study was to assess the effectiveness of traditional methods of conservation of silver fir forests. The study analyses the changes in the structure and species composition of a temperate forest excluded from the commercial silvicultural management for 50 years, and since then protected as a nature reserve. The study is based on a comparative analysis of phytosociological reléves made on permanent plots in 1961, 1982, 1994 and 2011. PCA and ecological indicator values were analyzed, as well as characteristic species based on an indicator value (IndVal) index. Results revealed significant and dynamic changes in the forest structure and composition. The mixed coniferous-broadleaved forest with Abies alba and diverse ground flora, considered in the 1960s as valuable and worthy of conservation, was found to have been anthropogenically transformed and unstable. Significant reduction in the human impact was followed by spontaneous regeneration of oak-hornbeam forest. However, the directional process of changes in vegetation was modified by such silvicultural treatments as selective cutting of trees and gap creation, all intended for silver fir maintenance. The results show that Carpinus betulus effectively outcompeted Pinus sylvestris, Picea abies, Quercus robur and A. alba. Changes in the forest overstory and understory caused temporal changes in the habitat conditions reflected in changes in the ground vegetation composition. The proportion of light-demanding and oligotrophic species significantly decreased, while the contribution of species with a wide ecological amplitude, i.e. more shade-tolerant and nutrient-demanding - increased. The share of A. alba was reduced. Species defined in this study as most valuable, should be actively protected, or selection of conservation targets should be re-evaluated.
\end{abstract}

Keywords: Abies alba; permanent study plots; successional changes; forest nature reserve; Poland

\section{Introduction}

Centuries of human impact on forests have caused drastic changes in the forest cover, structure and species composition $[1,2]$. As a result of intensive efforts of conservationists, ecologists and foresters, certain forest fragments have been excluded from the commercial use, both to preserve and to study the forest vegetation $[3,4]$. A sound understanding of how the previous land use and forest management affected the vegetation, and how this vegetation has been changed after the cessation of management, is of great importance to successful forest conservation [5,6]. Current and future successional trends may be predicted more accurately based on the knowledge of the management effects on forest biodiversity and the potential successional pathways after the cessation of management [7-9]. Protected forest areas can serve as reference sites to quantify the effects of silvicultural

\footnotetext{
*Corresponding author. Email: woziwoda@biol.uni.lodz.pl
}

Handling Editor: Jacek Herbich activities. They provide the necessary benchmark for naturebased silviculture in commercial forests $[10,11]$ and help to determine the best management options in silvicultural systems during sustainable forest management (SFM) and the implementation of forest naturalness [12-14].

Most forest reserves established in central Poland were designated to preserve diverse forest communities with the silver fir (Abies alba Mill.) $[15,16]$, mainly due to the growing awareness of this species decline throughout Europe $[17,18]$. Its preservation was perceived as an issue of great importance, also due to high environmental, social, and primarily economic significance of A. alba [19]. A long tradition of fir forests management has existed throughout the natural range of A. alba, where it is a significant forest component [20], and the most valuable and "natural" forest fragments have been included into the network of forest reserves. Reserves are partially protected, which means that if necessary the limited human intervention is allowed within their area to maintain high share of silver fir.

However, it may be assumed that the vegetation was not entirely natural when the reserves were created, as forests 
had been managed before that time $[15,20]$. The tree stand structure and composition had been significantly affected by previous clear-cuttings and remodeled by common planting of the Scots pine (Pinus sylvestris L.) and/or Norway spruce (Picea abies L.). The impact of the previous commercial use on the biodiversity may be observed decades later [21,22]. The conservation management focused on the maintenance of tree species composition may additionally modify the forest community structure. The preservation of the silver fir population requires specific forest activities: silvicultural strategies are aiming at the gradual removal of $P$. sylvestris or P. abies from the tree stand layer, and the reduction of canopy and subcanopy cover, usually by cutting down the European hornbeam (Carpinus betulus L.) or European beech (Fagus sylvatica L.) trees $[15,23]$. The natural restocking of $A$. alba is enhanced by the creation of forest gaps which provide opportunities for tree recruitment, establishment and development [24]. However, the final results of human intervention may sometimes differ from the expectations. Silvicultural operations, even the limited ones, result in site disturbances and provide an additional driving force for vegetation dynamics. Changes in the canopy cover and forest stand composition influence the site conditions [25-27], which are reflected in changes in the ground vegetation composition [28-31]. If a forest reserve have existed for half a century, it represents an excellent opportunity to research the changes in vegetation and the effectiveness of nature conservation in the environment exposed to a limited human impact.

The study was aimed at determining (i) whether the community structure and composition have changed during the conservation; and if so, (ii) what changes in the forest stand composition have occurred; (iii) whether there has been any successional trend observed in the vegetation; and, (iv) how the contemporary vegetation has been affected by anthropogenic activity before and after the establishment of the reserve.

\section{Material and methods}

\section{Study area}

The study was conducted in the Jamno nature reserve situated in central Poland $\left(51.70^{\circ} \mathrm{N}, 18.89^{\circ} \mathrm{E}\right.$; Fig. 1$)$, in the Wysoczyzna Łaska geographical region - a plain with an altitude of 157-160 $\mathrm{m}$ a.s.l. The landscape of the region was shaped under the Warta Glaciation between 180000 and $150000 \mathrm{BP}$ and modified under the Weichsel Glaciation between 25000 and $15000 \mathrm{BP}$. The geological substratum consists of heavy and medium clays covered by glaciofluvial sediments, sandy-gravel and loess, $0.7-2 \mathrm{~m}$ deep, with high clay content. Sandy-gravel deposits retain the rainfall water, which is accumulated over the impermeable clay layer. The groundwater level is no deeper than $1.5 \mathrm{~m}$. Proper clay soils dominate, and a small patches are occupied by typical podzolic soil (lessive soil). The topography and site conditions are homogenous in the reserve. The climate of the area is temperate with a mean annual temperature of $8.4^{\circ} \mathrm{C}$ and a mean annual precipitation $-605 \mathrm{~mm}$. The mean temperature of the coldest month (January) is $-2.5^{\circ} \mathrm{C}$, while that of the warmest month (July) is $18.2^{\circ} \mathrm{C}$ [32].
The nature reserve was established in 1959 to preserve the mixed-age population of $A$. alba with the oldest trees being 90-100 years old, growing in a mixed coniferous-broadleaf forest, and to preserve the floral diversity. The reserve is located close to the natural range limit of A. alba in Poland, however, the conditions of the site are still suitable for the growth of this tree species [15].

The reserve -22.4 ha in area, is located within the KobylaJamno forest complex of 627 ha (Fig. 1). This land has been covered with forest for over 200 years [33], however, the forest stands outside the reserve are younger than 140 years. The forest is owned by the State and managed by the State Forests for commercial purposes, apart from the reserve area (since 1959). The history of human impacts on the vegetation within the reserve is similar to that observed in the forest outside the reserve's borders [34]: the mature forest stand (100-120 years old) was cut and the new generation of $P$. sylvestris and Q. robur was planted. Small patches occupied by $A$. alba were left within plantation areas. Since the 1960 s, only a limited intervention has occurred within the reserve: $P$. sylvestris has been gradually removed and small canopy gaps were created by cutting of single $C$. betulus trees. All activities were focused on the maintenance of the A. alba dominance.

The description of the structure and the diversity of the tree stand as well as the detailed data on the measures undertaken to protect the silver fir population were presented in 1966 by Sowa and Szymański [35], in 1993 by Sowa et al. [36], in 2001 by Woziwoda [34] and in 2012 by Woziwoda et al. [37].

\section{Data source}

The vegetation of the reserve has been inventoried in detail four times: in 1961 [35], 1982 [36], 1994 [34] and 2011 [37]. Reléves were made and repeated using the same

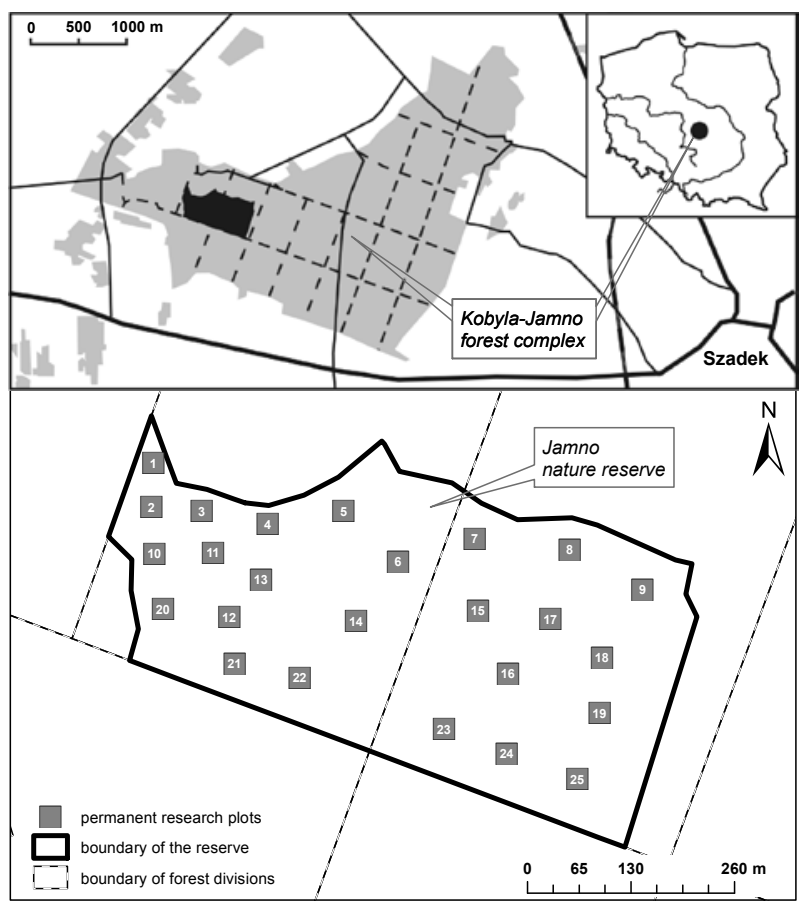

Fig. 1 Location of the study area and the distribution of permanent plots. 
method based on Braun-Blanquet's approach [38], on 25 permanent plots (19 in 1961; Fig. 1) located in homogenous patches of vegetation. The area of each individual plot is $400 \mathrm{~m}^{2}(20 \times 20 \mathrm{~m})$. In each plot, the cover of all vascular plant species (herbs, shrubs, trees) and mosses was estimated using a six-degree cover-abundance scale from " + ", representing a few individuals covering less than $1 \%$, to " 5 ", representing plant species covering more than $75 \%$ of the plot area. Based on the obtained results, both the number of species and the proportion of the area covered by a given species were estimated. Phytosociological data were used to compare and to analyze changes in the forest structure and composition over time.

\section{Data analysis}

PCA analysis was performed using CANOCO software version 5 [39]. General patterns of variation in species composition of the studied vegetation were characterized, and the results were divided based on time series: 1961, 1982, 1994 or 2011. This analysis was carried out for the entire data set, i.e. 94 samples. In the canonical analysis, ecological indicator values (EIV) were used as supplementary data to show the direction of changes with reference to ecological indices according to Zarzycki et al. [40]. The mean EIVs for light (L), moisture (M), soil fertility (Tr) and soil reaction $(\mathrm{R})$ were calculated for each of the four time series. Species defined in the Zarzycki's system as indifferent and not classified were excluded from the analysis. Mean EIVs were calculated for each sampling on the basis of all species present in a sample, taking into account cover values as weights. The Spearman coefficient was used to determine the correlation between $\mathrm{L}, \mathrm{M}, \mathrm{Tr}$ and $\mathrm{R}$ values and eigenvalues of the first two PCA axes.

Indicator values (IndVals) [41] calculated using PC-ORD 6.15 software [42] were used to determine which plant species were significantly associated with each sampling period. PC-ORD was also used to determine the significant maximum IndVals for each group using the Monte Carlo randomization test.

Changes in the species diversity in consecutive time series were analyzed by comparing the total number (noted in each of the four time series) and the mean number (noted per research plot) of woody species, herbs and mosses.

Changes in the forest community structure expressed by the mean cover value (with a standard deviation) of the vegetation layers of: higher trees (a1), lower trees (a2), shrubs (b), herbs (c) and mosses (d), were also analyzed. In addition, temporal changes in the mean cover values of A. alba, P. sylvestris, P. abies, C. betulus and Quercus robur were analyzed in the forest overstory ( $\mathrm{a} 1$ and $\mathrm{a} 2$ layers) and understory (b and c layers).

Differences between the times series were analysed with the one-way ANOVA test $(P<0.05)$. The normality was checked with the Shapiro-Wilk test, and the homogeneity of variance with Levene's test. Due to the lack of normal distribution of the calculated indices, the Box-Cox transformation was used.

The nomenclature of vascular plant species follows Mirek et al. [43] and mosses - Ochyra et al. [44].

\section{Results}

\section{Changes of the plant communities in time}

The results of the PCA analysis showed that the time, light intensity and soil fertility were the most important factors affecting the patterns observed in the vegetation (Fig. 2, Tab. 1). The first axis shows the variation resulting from the time function: the oldest historical data (from 1961) are located on graph quadrants I and IV, results from 1982 and younger occupy graph quadrants II and III. The second axis is strongly correlated with the light intensity and soil fertility indicators (Tab. 1).

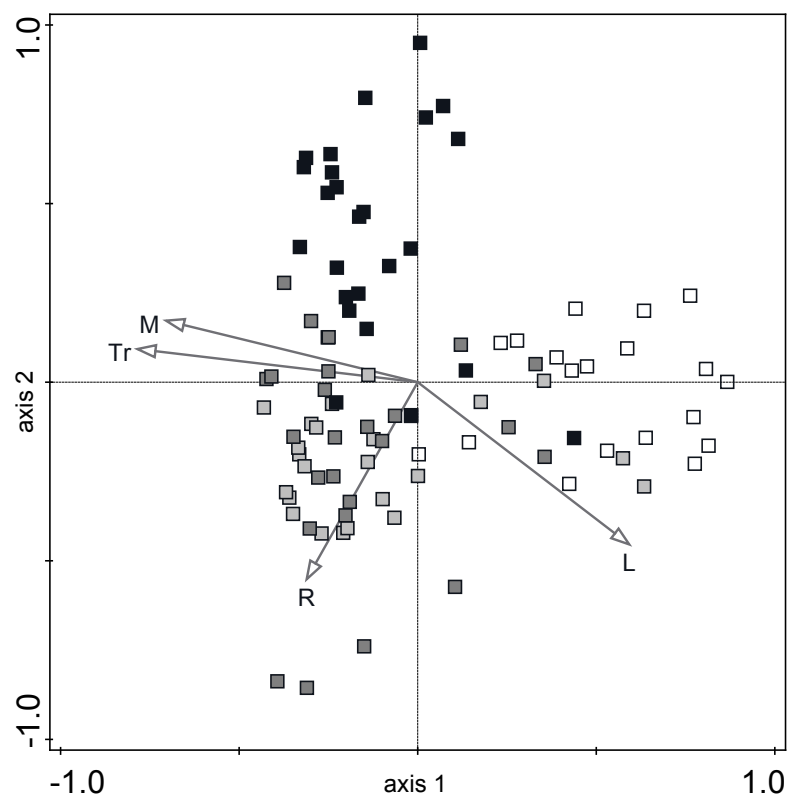

Fig. 2 PCA analysis of the phytosociological samples from 1961 (white squares), 1982 (light grey squares), 1994 (dark grey squares) and 2011 (black squares) completed with environmental variables: indicator values for light (L), soil moisture (M), soil fertility (Tr) and soil reaction ( $\mathrm{R}$; in accordance with Zarzycki et al. [40]).

Tab. 1 Coefficients of the Spearman rank correlation between sample scores on PCA axis 1 and 2, and the environmental variables $(P<0.05)$.

\begin{tabular}{lcccc} 
PCA axis & $\begin{array}{c}\text { Light } \\
(\mathbf{L})\end{array}$ & $\begin{array}{c}\text { Soil moisture } \\
(\mathbf{M})\end{array}$ & $\begin{array}{c}\text { Soil fertility } \\
(\mathbf{T r})\end{array}$ & $\begin{array}{c}\text { Soil reaction } \\
(\mathbf{R})\end{array}$ \\
\hline Axis 1 & 0.27 & -0.42 & -0.27 & $\mathrm{~ns}$ \\
Axis 2 & 0.55 & -0.48 & -0.63 & $\mathrm{~ns}$ \\
\hline
\end{tabular}

The forest community inventoried in 1961 was distinguished by the occurrence of species preferring pine forest with a partly open canopy (Tab. S1). Some of them, e.g. Genista tinctoria, Polytrichum juniperinum, Calluna vulgaris, Hieracium pilosella, are more closely associated with open moorlands or grasslands with acid and poor sandy soils than with forests. The next series from 1982 revealed the 
presence of species associated with forest patches disturbed by cutting of trees, such as Galeopsis bibida, Hieracium lachenalii or H. sabaudum. The community inventoried in 1994 was characterized by species commonly occurring in broadleaved forests, i.e. Deschampsia caespitosa and Milium effusum. The final time series was distinguished by the presence of a group of mosses, however, even though their IndVals were high (Tab. S1), most of them reached very low frequency and cover.

A total number of 166 plant species were noted during the 50 years of studies, including 24 woody species, 91 herbs and 53 bryophytes, but the total number of species noted in each individual time series did not exceed 104 (Tab. 2, Tab. 3).

The number of woody species fluctuated, the number of mosses gradually increased, and the number of herbs initially increased after the establishment of the reserve. However, this number has decreased since 1982. The changes in the mean number of all species per research plot were insignificant, while significant differences $(P<0.05)$ were noted in the mean number of herbs (decrease), and the mean number of mosses (increase; Tab. 2, Tab. 3).

\section{Community structure and composition}

During the 50 years of forest conservation, the canopy (a1) and subcanopy cover (a2, b) increased, while the herb and moss cover decreased (Tab. 2, Fig. 3). Meantime, the fluctuation of the layer cover was observed.

The mean cover of $A$. alba in the tree layers (a1 and a2) increased, the shrub layer cover fluctuated but generally decreased and the clayer cover considerably decreased (Tab. 4). The proportion of Q. robur, Picea abies and Pinus sylvestris gradually decreased in most forest layers. Although the

Tab. 2 Results of one-way ANOVA testing the effect of four community series on the mean value of ecological indicator values (EIV), mean number of woody, herbaceous and moss species, and mean cover values of higher and lower trees, shrubs, herbs and mosses. Due to the lack of normal distribution of the calculated indices, the Box-Cox transformation was used.

\begin{tabular}{lrccc}
\hline & \multicolumn{4}{c}{ Results of ANOVA } \\
\cline { 2 - 5 } Vegetation indices & MS effect & MS error & $\boldsymbol{F}$ & P-value \\
\hline EIV for: light (L) & 1.906 & 0.926 & 2.059 & ns \\
moisture (M) & 0.636 & 0.190 & 3.347 & $<0.05$ \\
soil reaction (R) & 0.664 & 1.035 & 0.641 & ns \\
soil fertility (Tr) & 3.476 & 0.865 & 4.019 & $<0.01$ \\
Number of species: & & & & ns \\
woody species & 247.544 & 130.678 & 1.894 & $<0.05$ \\
herbs & 13.198 & 4.745 & 2.781 & $<0.001$ \\
mosses & 320.477 & 34.253 & 9.356 & $<0.001$ \\
Cover value of: higher trees (a1) & 152.546 & 23.708 & 6.436 & $<0.001$ \\
lower trees (a2) & 14.598 & 4.281 & 3.410 & $<0.05$ \\
shrubs (b) & 4.637 & 2.509 & 1.848 & ns \\
herbs (c) & 15.290 & 0.596 & 25.663 & $<0.001$ \\
mosses (d) & 1.480 & 0.088 & 16.832 & $<0.001$ \\
\hline
\end{tabular}

Tab. 3 Changes in the species composition expressed by the number of species.

\begin{tabular}{|c|c|c|c|c|c|c|c|c|}
\hline \multirow{2}{*}{$\begin{array}{r}\text { Year: } \\
\text { No. of species: }\end{array}$} & \multicolumn{2}{|r|}{1961} & \multicolumn{2}{|r|}{1982} & \multicolumn{2}{|r|}{1994} & \multicolumn{2}{|r|}{2011} \\
\hline & total & mean $\pm S D$ & total & mean $\pm S D$ & total & mean $\pm S D$ & total & mean $\pm S D$ \\
\hline Woody species & 13 & $8.00^{\mathrm{a}, \mathrm{b}} \pm 1.29$ & 22 & $8.28^{\mathrm{a}} \pm 1.65$ & 13 & $7.12^{\mathrm{b}} \pm 1.30$ & 19 & $7.92^{\mathrm{a}, \mathrm{b}} \pm 1.66$ \\
\hline Herbs & 51 & $16.53^{\mathrm{a}, \mathrm{b}} \pm 3.44$ & 61 & $18.28^{\mathrm{b}} \pm 4.05$ & 55 & $19.96^{\mathrm{b}} \pm 4.36$ & 44 & $13.24^{\mathrm{a}} \pm 6.07$ \\
\hline Mosses & 12 & $6.37^{\mathrm{a}, \mathrm{b}} \pm 1.38$ & 21 & $5.16^{\mathrm{a}} \pm 2.85$ & 27 & $7.44^{\mathrm{b}} \pm 2.40$ & 40 & $13.32^{c} \pm 3.39$ \\
\hline In total & 76 & $30.89^{\mathrm{NS}} \pm 4.69$ & 104 & $31.72^{\mathrm{NS}} \pm 5.02$ & 95 & $34.52^{\mathrm{NS}} \pm 5.75$ & 103 & $34.48^{\mathrm{NS}} \pm 9.58$ \\
\hline
\end{tabular}

The mean number of species was counted per sample plot ( $n=19$ in 1961, and $n=25$ in 1982, 1994 and 2011). Boxes with the same letter are not significantly different, according to Tukey's post-hoc test. 


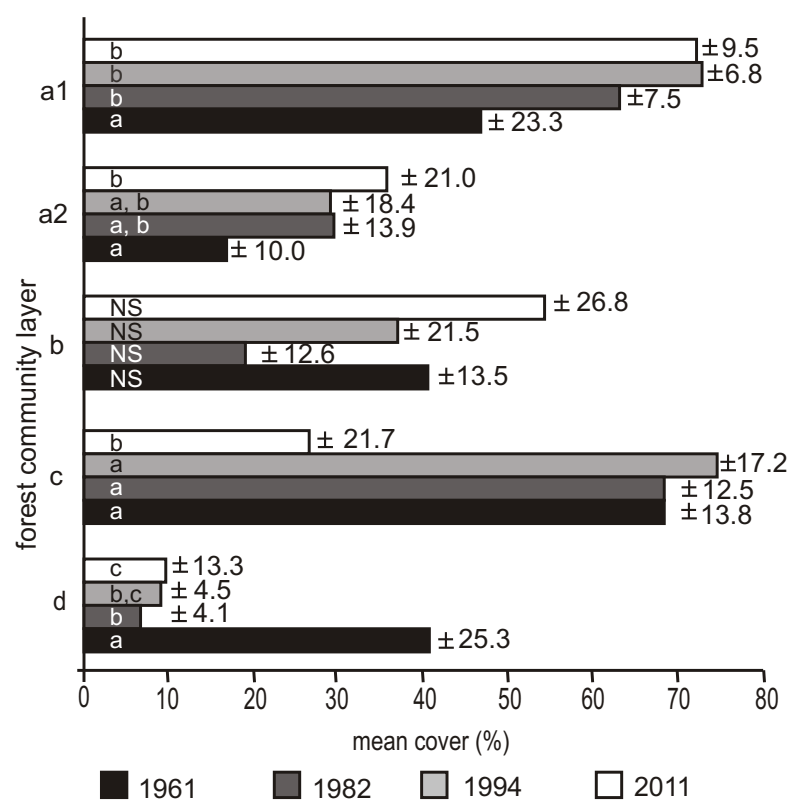

Fig. 3 Changes in the forest community structure expressed by the mean cover values ( \pm standard deviation) of the layers of higher trees (a1), lower trees (a2), shrubs (b), herbs (c) and mosses (d). Boxes with the same letter are not significantly different, according to Tukey's post-hoc test.

Tab. 4 Forest stand structure and composition in 1961, 1982, 1994 and 2011.

\begin{tabular}{lcccc}
\hline \multirow{2}{*}{$\begin{array}{l}\text { Tree } \\
\text { species }\end{array}$} & $\mathbf{4}$ Mean cover \pm SD \\
\cline { 2 - 5 } Abialb_a1 & $17.4 \pm 18.9$ & $19.8 \pm 13.9$ & $22.6 \pm 15.5$ & $23.1 \pm 17.6$ \\
Abialb_a2 & $7.8 \pm 7.1$ & $10.4 \pm 7.1$ & $10.1 \pm 7.5$ & $11.7 \pm 8.8$ \\
Abialb_b & $16.6 \pm 15.6$ & $11.6 \pm 6.8$ & $13.7 \pm 9.7$ & $13.0 \pm 10.5$ \\
Abialb_c & - & $4.1 \pm 3.5$ & $3.5 \pm 3.7$ & $0.7 \pm 0.9$ \\
Carbet_a2 & $3.7 \pm 6.4$ & $16.0 \pm 13.0$ & $14.2 \pm 16.7$ & $14.7 \pm 15.6$ \\
Carbet_b & $3.3 \pm 9.2$ & $0.5 \pm 1.4$ & $2.5 \pm 5.8$ & $22.5 \pm 21.0$ \\
Carbet_c & $3.7 \pm 9.2$ & $9.7 \pm 7.8$ & $26.0 \pm 22.0$ & $10.3 \pm 8.4$ \\
Querob_a1 & $17.8 \pm 19.7$ & $38.2 \pm 16.8$ & $41.3 \pm 15.3$ & $37.6 \pm 18.5$ \\
Querob_a2 & - & $1.8 \pm 3.8$ & $0.1 \pm 0.2$ & - \\
Querob_b & $6.4 \pm 12.2$ & $0.1 \pm 0.1$ & $0.2 \pm 1.0$ & - \\
Querob_c & $3.2 \pm 5.4$ & $1.4 \pm 1.8$ & $2.0 \pm 3.7$ & $0.1 \pm 0.2$ \\
Picabi_a1 & $0.1 \pm 0.1$ & $0.7 \pm 3.5$ & $0.7 \pm 3.5$ & - \\
Picabi_b & $8.6 \pm 12.3$ & $9.3 \pm 9.5$ & $9.0 \pm 7.9$ & $5.1 \pm 6.6$ \\
Picabi_c & $2.3 \pm 4.2$ & $0.2 \pm 0.2$ & $0.7 \pm 1.3$ & $0.1 \pm 0.2$ \\
Pinsyl_a1 & $6.2 \pm 10.4$ & $1.8 \pm 4.9$ & $0.4 \pm 1.4$ & $0.2 \pm 1.0$ \\
Pinsyl_c & $0.4 \pm 1.1$ & - & - & - \\
\hline
\end{tabular}

The silver fir (Abialb), European hornbeam (Carbet), pedunculate oak (Querob), Norway spruce (Picabi) and Scots pine (Pinsyl) in higher (a1) and lower (a2) tree layers, in the shrub layer (b) and in the ground layer $(c)$. contribution of $C$. betulus fluctuated across the subsequent time series and forest layers, its proportion considerably increased in general, except the c layer where it increased in 1994 and then decreased in 2011 (Tab. 4).

\section{ElVs fluctuations}

Values of ecological indices of light and soil acidity fluctuated during the studied period (Tab. 2, Fig. 4a,d), the moisture index increased across the first three time series, and then decreased (Tab. 2, Fig. 4b), while the fertility index increased (Tab. 2, Fig. 4c).

There was a strong correlation between environmental variables and the community composition (Tab. 5). A significant positive correlation occurred between the growing cover of species characteristic of broadleaved forests (Querco-Fagetea class) and C. betulus cover. This relationship is contrary to that observed in the cover of species characteristic of coniferous forests (Vaccinio-Piceetea class).

\section{Discussion}

The results of the study reveal significant and dynamic changes in the forest structure and composition. These were caused both by forest management and natural changes in the vegetation.

\section{Changes in the forest stand structure and composition}

The forest stand structure and composition of the studied forest had been affected by silvicultural practices, both before and after the nature reserve establishment. Abies alba dominated in the forest stand due to the fact that this tree was and still is preferred in the forest management, despite the fact that the habitat is more suitable for Q. robur or C. betulus. However, the cessation of intensive silvicultural activity after the establishment of the reserve favored the return of C. betulus as the dominant species. The massive development of $C$. betulus (reflected in its high cover index in the "c" layer in 1994; Tab. 4) prevented the expected natural restocking of $A$. alba in forest gaps which were artificially created by cutting of some trees from the canopy layer. After 17 years, numerous $C$. betulus sprouts reached the shrub (b) and lower tree (a2) layers where they formed a close subcanopy. Attempts to reduce $C$. betulus regrowth by repeated cutting appeared ineffective and made the natural regeneration of silver fir more difficult. Mechanical damage of $C$. betulus shoots is known to stimulate abundant re-sprouting in the plant and leads to the formation of an even denser shrub layer [45]. The gradual decrease in A. alba cover observed in the understory layers ( $b$ and $c$ ) may result in the loss of its co-dominant position in the future. Furthermore, the studies show that $A$. alba dies at the age of 200 years [46]. The oldest trees observed in the reserve are 140-150 years old, however, some of them have already died. In this situation, $A$. alba will be naturally replaced by the broadleaved species, or its further conservation will require additional silvicultural activities intended for $A$. alba recovery

The replacement of $A$. alba by broadleaf trees in forests excluded from the management has also been reported in beech forest habitats where it was substituted by F. sylvatica 

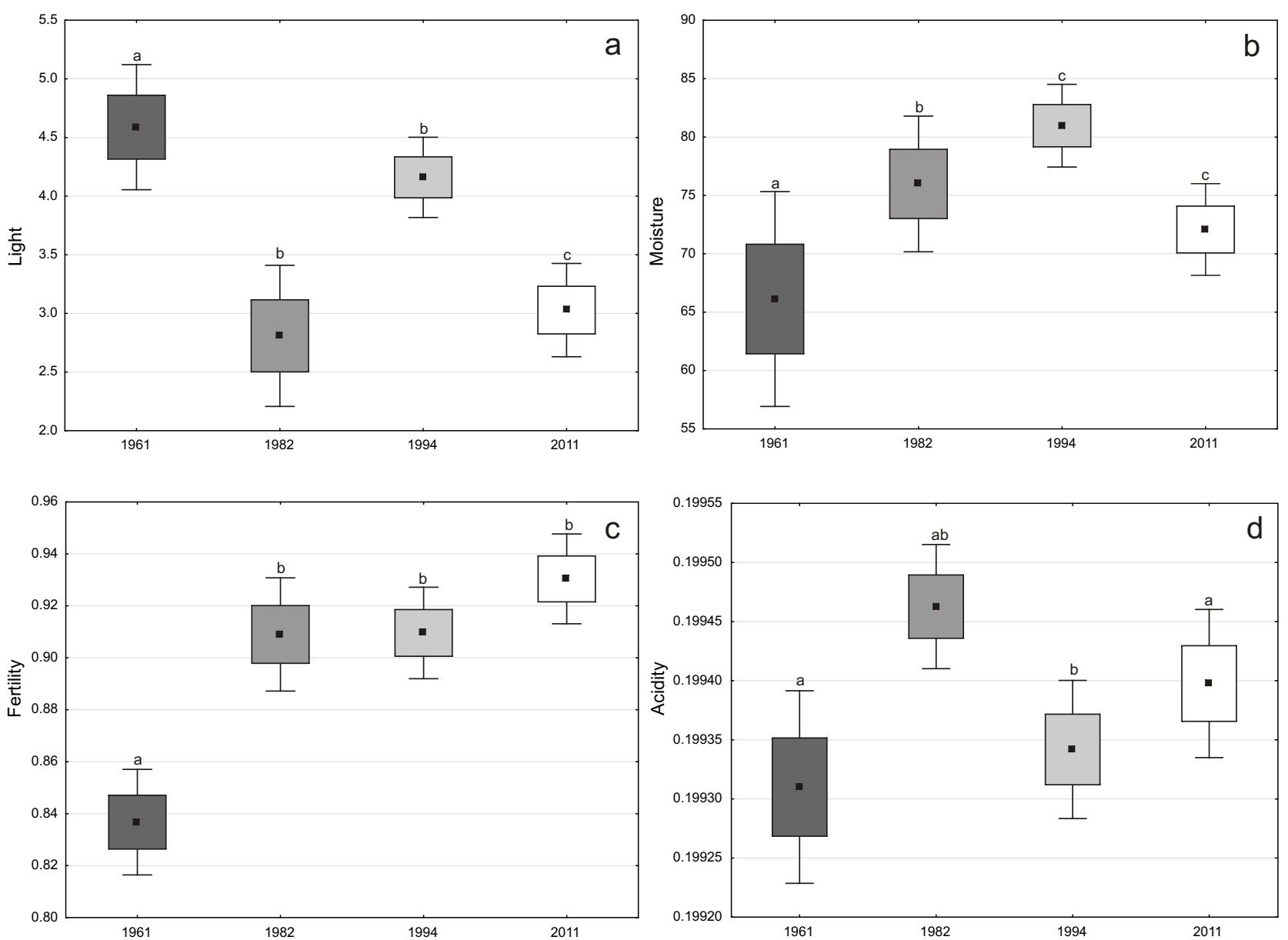

Fig. 4 Changes in mean: light (a), soil moisture (b), soil fertility (c), and soil acidity (d) indicator values in subsequent stages of the study; values after Box-Cox transformation. Boxes with the same letter are not significantly different, according to Tukey's post-hoc test.

Tab. 5 Pearson correlation coefficients among environmental variables: light, soil moisture, soil fertility, soil acidity and total of cover indices $\left(\sum_{c i}\right)$ of: herbs, mosses, Carpinus betulus (Carbet) in shrub (b) and herb (c) layers, and number of noted species.

\begin{tabular}{|c|c|c|c|c|c|c|c|c|}
\hline & Light & Moisture & Fertility & Acidity & $\boldsymbol{\Sigma}_{c i}$ herbs & $\boldsymbol{\Sigma}_{c i}$ mosses & $\begin{array}{l}\text { No. of } \\
\text { herbs }\end{array}$ & $\begin{array}{c}\Sigma_{c i} \text { Carbet } \\
(\mathbf{b}, \mathbf{c})\end{array}$ \\
\hline Light & $x$ & & & & & & & \\
\hline Moisture & $-0.213^{*}$ & $x$ & & & & & & \\
\hline Fertility & $-0.649^{* * *}$ & $0.149^{\mathrm{NS}}$ & $x$ & & & & & \\
\hline Acidity & $-0.431^{\star * *}$ & $-0.291^{\star *}$ & $0.595^{* * *}$ & $x$ & & & & \\
\hline$\Sigma_{c i}$ herbs & $0.167^{\mathrm{NS}}$ & $-0.055^{\mathrm{NS}}$ & $-0.125^{\mathrm{NS}}$ & $0.041^{\mathrm{NS}}$ & $x$ & & & \\
\hline$\Sigma_{c i}$ mosses & $0.318^{\star *}$ & $-0.244^{*}$ & $-0.460^{\star * *}$ & $-0.323^{* *}$ & $0.109^{\mathrm{NS}}$ & $x$ & & \\
\hline No. of herbs & $0.058^{\mathrm{NS}}$ & $-0.103^{\mathrm{NS}}$ & $0.155^{\mathrm{NS}}$ & $0.169^{\mathrm{NS}}$ & $0.624^{* * *}$ & $0.180^{\mathrm{NS}}$ & $x$ & \\
\hline$\Sigma_{c i}$ Carbet $(\mathbf{b}, \mathbf{c})$ & $-0.376^{* * *}$ & $0.140^{\mathrm{NS}}$ & $0.583^{* * *}$ & $0.304^{\star *}$ & $-0.180^{\mathrm{NS}}$ & $-0.238^{*}$ & $0.122^{\mathrm{NS}}$ & $x$ \\
\hline
\end{tabular}

The correlation are significant when $P<0.05$ ( $r$ value with asterisk). Since the calculated indices did not have a normal distribution, the Box-Cox transformation was used before Pearson's correlations. ${ }^{\star} P<0.05$; ${ }^{* *} P<0.01 ;{ }^{* * *} P<0.001$; ${ }^{\text {NS }}-$ non significant. 
[47-49]. The withdrawal of A. alba was the result of natural and spontaneous competition between tree species, accelerated by silvicultural operations. Due to the growing problems with $A$. alba regeneration and its recruitment into the tree layer [50,51], foresters and conservationists are still aware of the need to preserve this species [52], (but see [53]).

Dense canopy cover of $C$. betulus also likely resulted in a lack of regeneration of Q. robur (Tab. 4), hindering the survival and the growth of oak seedlings [54-56]. Moreover, thick crowns of $C$. betulus may well have caused Q. robur boughs to die off [57], which may be the cause of a decrease in this species cover value observed in the a2 layer. Also a gradual withdrawal of $P$. abies from the community can be observed (from b and c layers; Tab. 4), and this might be due to the growing dominance of $C$. betulus. A number of dead $P$. abies saplings found in 2011 were surrounded by dense thickets of $C$. betulus (author's observation). The natural regeneration of $A$. alba in the forest fragment was also supported by gradual cutting of $P$. sylvestris trees performed until the 1990s. The light-demanding $P$. sylvestris seedlings and saplings observed in the1960s naturally died due to the increasing shading of ground layers caused by C. betulus. Maciejewski and Szwagrzyk [49], Bernadzki et al. [58] and Kowalski [59] also reported almost complete lack of $P$. sylvestris regeneration under the close canopy of deciduous species.

In general, the intentional silvicultural operations affected and modified the forest structure and composition, but they also forced spontaneous changes within the forest community. However, the current overstory and understory structure and composition may also reflect differences in the development cycles and competition between the main tree species $[60,61]$. Other factors, not studied in this paper, may also significantly affect the dynamics of forest stands, e.g. the impact of climate change [62], natural disturbances [63] or species decline caused by lack of genetic variability [64].

\section{Changes in the habitat conditions reflected in ElVs}

Temporal changes in the forest overstory and understory, both anthropogenic and natural, caused changes in the habitat conditions reflected in the ground vegetation composition. Partly open forest canopy, observed in the 1960s (Fig. 3), composed mainly of P. sylvestris, A. alba and Q. robur (Tab. 4) favored the occurrence of light-demanding species on the forest floor (Fig. 4a). Withdrawal of these plants was caused by spontaneous regeneration of $C$. betulus after the establishment of the reserve and an increase in the canopy cover (Tab. 4). The dense understory layers also favored the establishment of shade-tolerant species, as demonstrated by the lowest measured light indicator value in 1982. Cutting of single C. betulus trees during the late 1980s temporarily increased the solar radiation incident on the forest floor, resulting in the regrowth of light-demanding species: a higher mean light value was recorded in 1994. However, the later development of $C$. betulus, both in the shrub layer and in the lower forest stand layer considerably reduced the insolation reaching the ground vegetation. This deterioration in light conditions was expressed by a decreased light value in 2011 (Fig. 4a). The increase in the moisture index observed till 1994 was likely a result of small gap formation [65]. As woody species produce litter with faster decomposition rates compared to coniferous trees [66], their growing advantage observed after the establishment of the reserve (Tab. 4) is likely to result in the increased general nutrient availability in the forest community. The gradual increase in the fertility index presented in Fig. $4 \mathrm{c}$ results from the establishment and persistence of nitrophilous species favoring the inflow of nutrients from the easily decomposable deciduous leaf litter [67]. The growing dominance of nitrophilous competitors over oligotrophic species may also be related to the enrichment of forest sites with nutrient deposition from the atmosphere [68,69] (but see [70]).

Increase in the soil fertility, however, negatively affects the occurrence of oligotrophic species which are easily outcompeted and replaced by meso-eutrophic plants [71], as it was observed in the studied forest (Fig. 4c). The frequency and abundance of plants characteristic of coniferous forests gradually decreased also due to the cutting of $P$. sylvestris and withdrawal of P. abies (Tab. 4), and the reduced inflow of acid litterfall [25,72]. Consequently, the fluctuations in the forest stand composition resulted in fluctuations of the soil acidity reflected in fluctuations of the acidity index (Fig. 4d). During the period under study the acidophilus vascular plant species disappeared gradually, while mesophilous plants dominated.

The increase in the proportion of C. betulus resulted in the increased amounts of leaf litter. Dense deciduous litter, which periodically cover the whole ground, can be an important factor limiting the growth of mosses $[73,74]$. This may partially explain the decrease in the ground moss cover (Fig. 3), despite the observed increase in the moss species diversity (Tab. 2).

\section{Decrease in the forest conservation value \\ despite the increase in biodiversity}

The overall plant diversity in the reserve was greater after 50 years compared to the conditions before the establishment of the reserve (Tab. 2). The richer flora observed after the reserve establishment can be explained by the growing diversity of micro-sites present under the coniferous-deciduous canopy [75]. The creation of gaps after cutting of some trees also considerably favored the increased biodiversity $[24,65]$. The increase in the moss diversity (Tab. 3) was also related to the availability of more heterogeneous substrates in the coniferous-deciduous forest stand [76], but it was also associated with the increased amounts of dead wood $[77,78]$. However, the disappearance of the oligotrophic and acidophilous species, whose occurrence additionally justified the establishment of the protected area, e.g. Lycopodium annotinum, Polypodium vulgare, Pyrola chlorantha and $P$. minor, lowered the "conservation value" of the reserve. These plants were replaced by common species with wider ecological amplitudes being effective competitors of the ecological specialists in the changing environment [79].

\section{Successional trends}

The observed changes in the ground vegetation composition which followed after the reserve establishment reflect the potential of the site, and they were inevitable after the cessation of silvicultural management [80]. The dominance 
of plants characteristic of coniferous forests observed in the 1960s should be attributed to the impact of the previous management strategy. The preference for coniferous trees within the site of oak-lime-hornbeam forest resulted in the degradation of the eutrophic community, which favored the establishment of oligotrophic species. Such human impact is described as a form of forest degeneration and is referred to as "pinetyzation" [81].

The withdrawal of species from the Vaccinio-Piceetea class and the simultaneous increase in the proportion of species from the Querco-Fagetea class occurring after the reserve establishment is a clear indication of the community transformation from degraded mixed coniferous-broadleaved forest to natural broadleaved forest with coniferous admixture. The regeneration of an oak-lime-hornbeam community within a conserved area, formerly covered with mixed coniferousbroadleaved forest has been already reported by Bernadzki et al. [58], Czerepko [82] and Kopeć et al. [83]. Moreover, this tendency is commonly observed not only in protected, but also in commercial forests $[69,84]$. It can also be observed throughout the entire studied forest complex within the site of the oak-hornbeam community [34]. These changes are favored by the implementation of SFM in the 1990s, which requires, inter alia, the forest stand to be compatible with site conditions. This involves a more natural tree species composition to be re-established with the use of natural woody species regeneration. As a result, the community protected within the reserve area became homogenous with those occurring outside the reserve, (i.e. in the commercial forest), which raises the question of whether the reserve can continue to exist under the present strategy. However, this secondary forest set aside from the silvicultural management and reverting to a natural community may have an important direct conservation function, insofar that it may be the site where future old-growth hornbeam forest will develop.

\section{Conclusions}

The main objective of the reserve establishment was to preserve the forest fragment built by A. alba, P. sylvestris

\section{Acknowledgments}

The authors would like to thank anonymous reviewers for useful comments. The study was financially supported by the Department of Geobotany and Plant Ecology, University of Lodz..

\section{Authors' contributions}

The following declarations about authors' contributions to the research have been made: concept of the study, literature review, writing the manuscript: BW; data analysis: BW; statistical analysis: DK.

\section{Competing interests}

No competing interests have been declared.

\section{Supplementary material}

The following supplementary material for this article is available online at http://pbsociety.org.pl/journals/index.php/asbp/rt/suppFiles/ asbp.2015.024/0: and Q. robur and characterized by a diverse ground flora characteristic of mixed-coniferous forests. The plant community, described in the 1960s as valuable and worthy of conservation was, however, transformed by the previous forest management. The vegetation described in 1982 and 1994 represents transitional stages between anthropogenicallydegraded and spontaneously-regenerating oak-hornbeam forest. After 50 years of conservation, the forest structure and composition is still unstable and will change as a result of intentional modifications to the forest stand layer from the 1980s and the regeneration of the hornbeam cohort.

The following conclusions were reached from the analysis of the inventories from 1961, 1982, 1994 and 2011:

(i) establishment of the reserve was followed by spontaneous regeneration of natural forest vegetation degraded in the past by the commercial forest use. The increase in the proportion of spontaneously regenerating $C$. betulus and the shift in the species composition from light-demanding, acidophilous and oligotrophic species towards more shade-tolerant and nutrient-demanding species are the clear indicators of the gradual and long-term changes in the vegetation. They indicate the targeted turnover from the mixed coniferous-broadleaved community to the broadleaved forest one;

(ii) the creation of gaps in the oak-hornbeam canopy do not necessarily favor the natural restocking of A. alba and $Q$. robur due to the high competitiveness of $C$. betulus. The observed decrease in A. alba cover indicates the species withdrawal from the forest community, which may result in the retreat of this species in the next 30-40 years;

(iii) the loss of forest distinctiveness raises the question of further existence of the reserve under the present conditions. In the studied case the conservation through active management should be implemented to preserve $A$. alba and oligotrophic, acidophilous and heliophilous species identified here as being the most valuable, or the conservation targets should be changed.

1. Tab. S1: indicator value scores (IndVal) and their associated significance $(P)$ obtained by the Monte Carlo permutations test for the plant species identified in the four time series.

\section{References}

1. Kirby KJ, Watkins C, editors. The ecological history of european forests. Wallingford: CAB International; 1998.

2. Ellenberg H, Leuschner C. Vegetation Mitteleuropas mit den Alpen. 6 Aufl. Stuttgart: Ulmer-Verlag; 2010.

3. Frank G, Parviainen J, Vandekerkhove K, Latham J, Schuck A, Little $\mathrm{D}$, editors. Protected forest areas in Europe - analysis and harmonisation (PROFOR): results, conclusions and recommendations. Vienna: Federal Research and Training Centre for Forests Natural Hazards and Landscape; 2007.

4. Parviainen J, Schuck A. Maintenance conservation and appropriate enhancement of biological diversity in forest ecosystems. In: FOREST EUROPE UNECE and FAO: state of Europe's Forests 2011. Status and trends in sustainable forest management in Europe. Oslo: MCPF in Europe. FOREST EUROPE Liaison Unit Oslo; 2011. p. 65-97. 
5. Josefsson T, Hörnberg G, Östlund L. Long-term human impact and vegetation changes in a boreal forest reserve: implications for the use of protected areas as ecological references. Ecosystems. 2009;12:1017-1036. http://dx.doi.org/10.1007/s10021-009-9276-y

6. Kraus D, Krumm F, editors. Integrative approaches as an opportunity for the conservation of forest biodiversity. Freiburg: European Forest Institute; 2013.

7. Hahn K, Emborg J, editors. Suserup Skov: structures and processes in a temperate deciduous forest reserve. Oxford: Wiley-Blackwell; 2007. (Ecological Bulletins; vol 52).

8. Ruprecht H, Steiner H, Frank G, Vacik H. Long term monitoring of natural regeneration in natural forest reserves in Austria - results from the ELENA project. Proceedings of the 5th Symposium for Research in Protected Areas, 10-12 June 2013. Mittersill: Nationalpark Hohe Tauern; 2013. p. 671-676.

9. Heiri C, Wolf A, Rohrer L, Brang P, Bugmann H. Successional pathways in Swiss mountain forest reserves. Eur J For Res. 2012;131:503-518. http://dx.doi.org/10.1007/s10342-011-0525-1

10. Frelich LE, Cornett MW, White MA. Controls and reference conditions in forestry: the role of old-growth and retrospective studies. J For. 2005;103:339-344.

11. Nagel TA, Zenner EK, Brang P. Research in old-growth forests and forest reserves: implications for integrated forest management. In: Kraus D, Krumm F, editors. Integrative approaches as an opportunity for the conservation of forest biodiversity. Freiburg: European Forest Institute; 2013. p. 44-50.

12. Gamborg C, Larsen JB. "Back to nature" - a sustainable future of forestry? For Ecol Manage. 2003;179:559-571. http://dx.doi.org/10.1016/ S0378-1127(02)00553-4

13. Rametsteiner E, Mayer P. Sustainable forest management and PanEuropean forest policy. In: Angelstam P, Dönz-Breuss M, Roberge JM, editors. Target and tools for the maintenance of forest biodiversity. Oxford: Blackwell Science; 2004. p. 51-57. (Ecological Bulletins; vol 51).

14. Winter S, Vrška T, Begehold H. Forest naturalness as a key to forest biodiversity preservation. In: Kraus D, Krumm F, editors. Integrative approaches as an opportunity for the conservation of forest biodiversity. Freiburg: European Forest Institute; 2013. p. 52-63.

15. Białobok S, editor. Silver fir Abies alba Mill. - our forest trees. Warszawa: PWN; 1983. (vol 4).

16. Woziwoda B. The silver fir Abies alba Mill. reserve conservation on its range limit in the aspect of vegetation transformation. Studia Naturae. 2008;54(2):199-212.

17. Jaworski A. Fir regression in Polish mountain areas. Eur J Forest Pathol. 1982;12(3):143-149. http://dx.doi.org/10.1111/j.1439-0329.1982. tb01387.x

18. Larsen JB. Silver fir decline - a new hypothesis concerning this complex decline syndrome in Abies alba (Mill). Forstwiss Centralbl. 1986;105:381-396. http://dx.doi.org/10.1007/BF02741747

19. Elling W, Dittmar C, Pfaffelmoser K, Rötzer T. Dendroecological assessment of the complex causes of decline and recovery of the growth of fir (Abies alba Mill.) in southern Germany. For Ecol Manage. 2009;257:1175-1187. http://dx.doi.org/10.1016/j.foreco.2008.10.014

20. Kramer W. Die Weisstanne (Abies alba Mill.) in Ost- und Südosteuropa: Eine Zustandbeschreibung. Stuttgart: Gustav Fischer Verlag; 1992.

21. Hermy M, Verheyen K. Legacies of the past in the present-day forest biodiversity: a review of past land-use effects on forest plant species composition and diversity. In: Nakashizuka T, editor. Sustainability and diversity of forest ecosystems. Tokyo: Springer Japan; 2007. p. 361-371. http://dx.doi.org/10.1007/978-4-431-73238-9_1

22. Paillet Y, Bergés L, Hjältén J, Ódor P, Avon C, Bernhardt-Römermann $\mathrm{M}$, et al. Biodiversity differences between managed and unmanaged forests: meta-analysis of species richness in Europe. Conserv Biol. 2010;24(1):101-112. http://dx.doi. org/10.1111/j.1523-1739.2009.01399.x

23. Botallico F, Travaglini D, Fiorentini S, Lisa C, Nocentini S. Stand dynamics and natural regeneration in silver fir (Abies alba Mill.) plantations after traditional rotation age. iForest; 2014;7:313-323. http://dx.doi.org/10.3832/ifor0985-007

24. Dobrowolska D, Veblen T. Treefall-gap structure and regeneration in mixed Abies alba stands in central Poland. For Ecol Manage. 2008;255:3469-3476. http://dx.doi.org/10.1016/j.foreco.2008.02.025

25. Augusto L, Ranger J, Binkley D, Rothe A. Impact of several common tree species of European temperate forests on soil fertility. Ann For Sci. 2002;59:233-253. http://dx.doi.org/10.1051/forest:2002020

26. Flinn KM, Marks PL. Agricultural legacies in forest environments: tree communities, soil properties and light availability. Ecol Appl. 2007;17:452-463. http://dx.doi.org/10.1890/05-1963

27. Collier M, Farrell EP. The environmental impact of planting broadleaved trees on acid-sensitive soils. Literature review. Dublin: COFORD; 2007.

28. Emborg J. Understorey light conditions and regeneration with respect to the structural dynamics of a near-natural temperate deciduous forest in Denmark. For Ecol Manage. 1998;106:83-95. http://dx.doi. org/10.1016/S0378-1127(97)00299-5

29. Augusto L, Dupouey JL, Ranger J. Effects of tree species on understorey vegetation and environmental conditions in temperate forests. Ann For Sci. 2003;60:823-831. http://dx.doi.org/10.1051/forest:2003077

30. Verheyen K, Honnay O, Motzkin G, Hermy M, Foster DR. Response of forest plant species to land-use change: a life-history trait-based approach. J Ecol. 2003;91:563-577. http://dx.doi. org/10.1046/j.1365-2745.2003.00789.x

31. Bartels SF, Chen HYH. Interactions between overstorey and understorey vegetation along an overstorey compositional gradient. J Veg Sci. 2013;24(3):543-552. http://dx.doi. org/10.1111/j.1654-1103.2012.01479.x

32. Program of nature conservation - Poddębice Forest District. State on the 1st Jan 2007. Łódź: BULiGL; 2007.

33. Majchrowska A, Woziwoda B. Effects of forest history on the biodiversity of vascular plants flora. In: Holeksa J, Babczyńska-Sendek B, Wika S, editors. The role of geobotany in biodiversity conservation. Katowice: University of Silesia; 2009. p. 165-174.

34. Woziwoda B. Phytosociological diversity and contemporary changes of oak-hornbeam forests in the northern part of Wysoczyzna Łaska geographical region [PhD thesis]. Łódz: Department of Geobotany and Plant Ecology, University of Łódz; 2001.

35. Sowa R, Szymański J. Jamno nature reserve. Zesz Nauk UŁ Ser II. 1966;22:105-119.

36. Sowa R, Filipiak E, Andrzejewski H. Regeneration of oak-hornbeam forest with A. alba in the Jamno nature reserve. Acta Univ Lodz Folia Bot. 1993;10:3-21.

37. Woziwoda B, Pawicka K, Wolski GJ. Characteristic of oak-hornbeam forest with silver fir in Jamno nature reserve. Biuletyn Szadkowski. 2012;12:127-143.

38. Braun-Blanquet J. Pflanzensoziologie Grundzüge der Vegetationskunde. 3rd ed. Wien: Springer Verlag; 1964. http://dx.doi. org/10.1007/978-3-7091-8110-2

39. ter Braak CJF, Šmilauer P. Canoco reference manual and user's guide: software for ordination (ver 5.0). Ithaca, NY: Microcomputer Power; 2012.

40. Zarzycki K, Trzcińska-Tacik H, Różański W, Szeląg Z, Wołek J, Korzeniak U, editors. Ecological indicator values of vascular plants of Poland. Kraków: W. Szafer Institute of Botany, Polish Academy of Sciences; 2002. (Biodiversity of Poland; vol 2).

41. Dufrêne M, Legendre P. Species assemblages and indicator species: The need for a flexible asymmetrical approach. Ecol Monogr. 1997;67:345-366. http://dx.doi.org/10.2307/2963459

42. McCune B, Mefford MS. PcOrd multivariate analysis of ecological data version 606. Gleneden Beach, OR: MjM Software Design; 2011.

43. Mirek Z, Piękoś-Mirkowa H, Zając A, Zając M, editors. Vascular plants of Poland. A checklist. Kraków: W. Szafer Institute of Botany. Polish Academy of Sciences; 2002. (Biodiversity of Poland; vol 1). 
44. Ochyra R, Żarnowiec J, Bednarek-Ochyra H. Census catalogue of Polish moses. Kraków: W. Szafer Institute of Botany, Polish Academy of Sciences; 2003. (Biodiversity of Poland; vol 3).

45. Bobiec A. The influence of gaps on tree regeneration: a case study of the mixed lime-hornbeam (Tilio-Carpinetum Tracz. 1962) communities in the Białowieża primeval forest. Pol J Ecol. 2007;55:441-455.

46. Podlaski R. A development cycle of the forest with fir (Abies alba Mill.) and beech (Fagus sylvatica L.) in its species composition in the Świętokrzyski National Park. J For Sci. 2004;50(2):55-66.

47. Vrška T, Adam D, Hort L, Kolár T, Janík D. European beech (Fagus sylvatica L.) and silver fir (Abies alba Mill.) rotation in the Carpathians - a developmental cycle or a linear trend induced by man? For Ecol Manage. 2009;258:347-356. http://dx.doi.org/10.1016/j. foreco.2009.03.007

48. Klopcic M, Boncina A. Stand dynamics of silver fir (Abies alba Mill.)European beech (Fagus sylvatica L.) forests during the past century: a decline of silver fir? Forestry. 2011;84(3):259-271. http://dx.doi. org/10.1093/forestry/cpr011

49. Maciejewski Z, Szwagrzyk J. Long-term changes in stand composition of natural forest associations on the Roztocze Highlands (eastern Poland). Pol J Ecol. 2011;59(3):535-549.

50. Diaci J, Rozenbergar D, Boncina A. Stand dynamics of Dinaric old-growth forest in Slovenia: are indirect human influences relevant? Plant Biosyst. 2010;144:194-201. http://dx.doi. org/10.1080/11263500903560785

51. Ficko A, Poljanec A, Boncina A. Do changes in spatial distribution structure and abundance of silver fir (Abies alba Mill.) indicate its decline? For Ecol Manage. 2011;261: 844-854. http://dx.doi. org/10.1016/j.foreco.2010.12.014

52. Lombardi F, Klopcic M, Di Martino P, Tognetti R, Chirici G, Boncina A, et al. Comparison of forest stand structure and management of silver fir - European beech forests in the Central Apennines Italy and in the Dinaric Mountains Slovenia. Plant Biosyst. 2012;146(1):114-123. http://dx.doi.org/10.1080/11263504.2011.623190

53. Volarik D, Hedl R. Expansion to abandoned agricultural land forms an integral part of silver fir dynamics. For Ecol Manage. 2013;292:39-48. http://dx.doi.org/10.1016/j.foreco.2012.12.016

54. Lorimer CG, Chapman JW, Lambert WD. Tall understorey vegetation as a factor in the poor development of oak seedlings beneath mature stands. J Ecol. 1994;82:227-237.

55. Bobiec A, Jaszcz E, Wojtuniak K. Oak (Quercus robur L.) regeneration as a response to natural dynamics of stands in European hemiboreal zone. Eur J For Res. 2011;130:785-797. http://dx.doi.org/10.1007/ s10342-010-0471-3

56. McEwan RW, Dyer JM, Pederson N. Multiple interacting ecosystem drivers: toward an encompassing hypothesis of oak forest dynamics across eastern North America. Ecography. 2011;34:244-256. http:// dx.doi.org/10.1111/j.1600-0587.2010.06390.x

57. Drobyshev I, Niklasson M, Linderson H, Sonesson K, Karlsson M, Nilsson SG, et al. Lifespan and mortality of old oaks - combining empirical and modelling approaches to support their management in southern Sweden. Ann For Sci. 2008;65:401. http://dx.doi.org/10.1051/ forest:2008012

58. Bernadzki E, Bolibok L, Brzeziecki B, Zajączkowski J, Żybura H. Compositional dynamics of natural forests in the Białowieża National Park north-eastern Poland. J Veg Sci. 1998;9:229-238. http://dx.doi. org/10.2307/3237122

59. Kowalski M. The development of natural forest stands in the Białowieża National Park. Folia For Pol Ser A For. 1993;35:35-47.

60. Nakashizuka T. Species coexistence in temperate mixed deciduous forests. Trends Ecol Evol. 2001;16:205-210. http://dx.doi.org/10.1016/ S0169-5347(01)02117-6

61. Motta R, Garbarino F. Stand history and its consequences for the present and future dynamic in two silver fir (Abies alba Mill.) stands in the high Pesio Valley (Piedmont Italy). Ann For Sci. 2003;60:361-370. http://dx.doi.org/10.1051/forest:2003027

62. Fitzgerald J, Lindner M, editors. Adapting to climate change in
European forests - results of the MOTIVE project. Sofia: Pensoft Publishers; 2013.

63. Klopcic M, Jerina K, Boncina A. Long-term changes of structure and tree species composition in Dinaric uneven-aged forests: are red deer an important factor? Eur J For Res. 2010;129:277-288. http://dx.doi. org/10.1007/s10342-009-0325-Z

64. Paule L, Gömöry D, Longauer R, Krajmerová D. Patterns of genetic diversity distribution in three main Central European montane tree species: Picea abies Karst., Abies alba Mill. and Fagus sylvatica L. Lesn Cas For J. 2001;47(2):152-163.

65. Hahn K. Comparative studies of gapphase regeneration in managed and natural beech forests in different parts of Europe: Denmark. Copenhagen: University of Copenhagen; 2004.

66. Cote L, Brown S, Paré D, Fyles JW, Bauhus J. Dynamics of carbon and nitrogen mineralization in relation to stand type, stand age and soil texture in the boreal mixedwood. Soil Biol Biochem. 2000;32:1079-1090.

67. Hofmeister J, Hošek J, Modrý M, Roleček J. The influence of light and nutrient availability on herb layer species richness in oak-dominated forests in central Bohemia. Plant Ecol. 2009;205:57-75. http://dx.doi. org/10.1007/s11258-009-9598-Z

68. Bobbink R, Hornung M, Roelofs JGM. The effects of air-borne pollutants on species diversity in natural and semi-natural European vegetation. J Ecol. 1998;86:717-738. http://dx.doi. org/10.1046/j.1365-2745.1998.8650717.x

69. Matuszkiewicz JM, editor. Geobotanical identification of the development tendencies in forest associations in the regions of Poland. Warsaw: Monografie IGiPZ im. S. Leszczyckiego PAN; 2007.

70. Verheyen K, Baeten L, de Frenne P, Bernhardt-Römermann M, Brunet J, Cornelis J, et al. Driving factors behind the eutrophication signal in understorey plant communities of deciduous temperate forests. J Ecol 2012;100:352-365. http://dx.doi.org/10.1111/j.1365-2745.2011.01928.x

71. Strengbom J, Nordin A, Näsholm T, Ericson L. Slow recovery of boreal forest ecosystem following decreased nitrogen input. Funct Ecol. 2001;15:451-457.

72. Diekmann M, Dupré C. Acidification and eutrophication of deciduous forests in northwestern Germany demonstrated by indicator species analysis. J Veg Sci. 1997;8:855-864. http://dx.doi.org/10.2307/3237030

73. Stratsev N, Lieffers VJ, Landhäusser SM. Effects of leaf litter on the growth of boreal feather mosses: implications for forest floor development. J Veg Sci. 2008;19:253-260. http://dx.doi. org/10.3170/2008-8-18367

74. Maciejewski Z, Zubel R. Long-term changes in the Leucobryo-Pinetum community: interactions between the tree-stand understorey and moss layer. Ann UMCS C. 2009;64(2):23-34. http://dx.doi.org/10.2478/ v10067-010-0011-Z

75. Cannell MGR, Malcolm DC, Atterson J, editors. The ecology of mixed species stands and trees. Oxford: Blackwell Scientific Publications; 1992.

76. Glime JM. Bryophyte ecology. Vol. 1. Physiological ecology. E-book sponsored by Michigan Technological University and the International Association of Bryologist [Internet]. 2007 [cited 2015 Jun 11]; Available from: http://www.bryoecol.mtu.edu/

77. Andersson LI, Hytteborn H. Bryophytes and decaying wood - a comparison between managed and natural forest. Ecography. 1991;14:121130. http://dx.doi.org/10.1111/j.1600-0587.1991.tb00642.x

78. Vellak K, Paal J. Diversity of bryophyte vegetation in some forest types in Estonia: a comparison of old unmanaged and managed forests. Biodivers Conserv. 1999;8:1595-1620. http://dx.doi. org/10.1023/A:1008927501623

79. Diekmann M, Lawesson JE. Shifts in ecological behaviour of herbaceous forest species along a transect from northern Central to North Europe. Folia Geobot. 1999;34:127-141. http://dx.doi.org/10.1007/ BF02803080

80. Hoonay O, Hermy M, Coppin P. Impact of habitat quality on forest plant species colonization. For Ecol Manage. 1999;115:157-170. 
81. Olaczek R. Synanthropization of phytocoenoses. Memorabilia Zool. 1982;37:93-112.

82. Czerepko J. Development of vegetation in managed Scots pine (Pinus sylvestris L.) stands in an oak-lime-hornbeam forest habitat. For Ecol Manage. 2004;202:119-130. http://dx.doi.org/10.1016/j. foreco.2004.07.033
83. Kopeć D, Halladin-Dąbrowska A, Zając I. Flora dynamics in strictly protected area: Świnia Góra Nature Reserve. Pol J Environ Stud. 2011;20(1):107-113.

84. Zerbe S. Restoration of natural broad-leaved woodland in Central Europe on sites with coniferous forest plantations. For Ecol Manage. 2002;167:27-42. http://dx.doi.org/10.1016/S0378-1127(01)00686-7 